\title{
ESTONIAN TRACES IN THE TREE OF LIFE CONCEPT AND IN THE LANGUAGE FAMILY TREE THEORY
}

\author{
Urmas Sutrop \\ Institute of the Estonian Language, Tallinn, \\ and the University of Tartu
}

\begin{abstract}
In this paper the tree model - a well-formed tree is shortly described. After that the language family tree model by August Schleicher is treated and compared with the Charles Darwin's tree of life diagram and metaphor. The development of the idea of the linguistic trees and the tree of life is considered historically. Earlier models - scala naturae - and tree models, both well-formed and not-well-formed are introduced. Special attention is paid to the scholars connected to Estonia who developed the idea of tree models: Georg Stiernhielm was the first who pictured a language tree already in 1671; Karl Eduard Eichwald published an early tree of animal life in 1829; and Karl Ernst von Baer influenced the tree of life models and diagrams of Charles Darwin.
\end{abstract}

Keywords: tree models, Karl Ernst von Baer, Charles Darwin, Karl Eduard Eichwald, August Schleicher, Georg Stiernhielm, Estonia

\section{What is the tree model?}

Let us first of all look at some types of tree models and the characteristics that make a model a tree model. Tree models can be divided into two larger groups: phenetic trees and cladograms. Various features must be considered in compiling a tree model, such as joint primitive features, joint acquired features, convergent and diffuse features (contacts). In constructing phenetic trees, all features are taken into account, including the primitive ones. In compiling cladograms, however, primitive features are ignored and the focus is on acquired features. In case the phenetic trees are quantitative, cladograms are only qualitative. Cladograms therefore only show the topology of tree 
branching. Phenetic trees, on the other hand, additionally show the length of branches and thus the time of separation. These types can also be called metrical and topological trees. The speed of development and other temporal parameters can only be considered in phenetic or metrical trees; in linguistics, for example, this forms the basis for lexicostatistical or glottochronological method. Linguists also often construct intuitive trees, where no single correct method is used.

The tree models have at least two topological features that must be taken into account:

1) Every well-formed language family tree has at least one root; if a structure has two roots, it means that there are several trees or a forest;

2) The tree branches cannot cross or grow together. If the tree's branches cross or have merged, it is a web model.

Tree models must additionally express:

3) The genealogical relationship between the successive nodes, i.e. trees should not merely classify. For example trees originating in generative grammar, which are designated for sentence structure analysis, are not regarded as language family trees. If a model resembling a tree model does not express any connections of descent, it could be a scala naturae (Jacob's ladder, the great chain of being).

A tree has the following parts: stem, branches, leaves, nodes, rooted trees also have a root. Bush model is a special case of tree model, where the stem is missing; all (main) branches develop straight from the root. See Ruvolo (1987) and Hoeningswald (1987) about phenetic (metrical) and cladistic (topological) approaches of reconstructing both the tree of life, as well as the language family tree models.

\section{Schleicher's language family tree theory}

It is generally assumed in linguistics that August Schleicher's language family tree theory and model were greatly influenced by Charles Darwin's On the Origin of Species (1859). 
The manuals of linguistics illustrate the birth of language family trees and language family tree theory (Stammbaumtheorie) with a reference to Schleicher's Compendium (Schleicher 1861). However, Schleicher had actually presented the language family tree theory a year earlier, together with numerous illustrations of the language family tree in the book German Language (Schleicher 1860). The leaves of the ideal language family tree here (Fig. 1) are the language subspecies, i.e. dialects (x), segment (c) shows the species of languages, i.e. languages emerging from one proto-language as a result of branching (a). Comparing this drawing with the only tree diagram presented by Darwin in his On the Origin of Species (Fig. 2) (Darwin 1859: diagram for page 116), we see both differences and similarities.

The most striking similarity is evident in horizontal support lines (aa, bb, cc, xx). For Schleicher these mark certain time intervals, whereas for Darwin they mean a thousand or ten thousand generations. A significant difference is the fact that according to Darwin, many branches of evolution become extinct, and the evolution tree is no longer symmetrical. Schleicher's ideal tree, on the other hand, is perfectly symmetrical.

In 1863 he published a book Darwin's Theory and Linguistics, with a subtitle A Public Circular to Dr. Ernst Haeckel (Schleicher 1863). Ernst Haeckel's house museum in Jena keeps a copy of that book where Schleicher himself added to the sub-

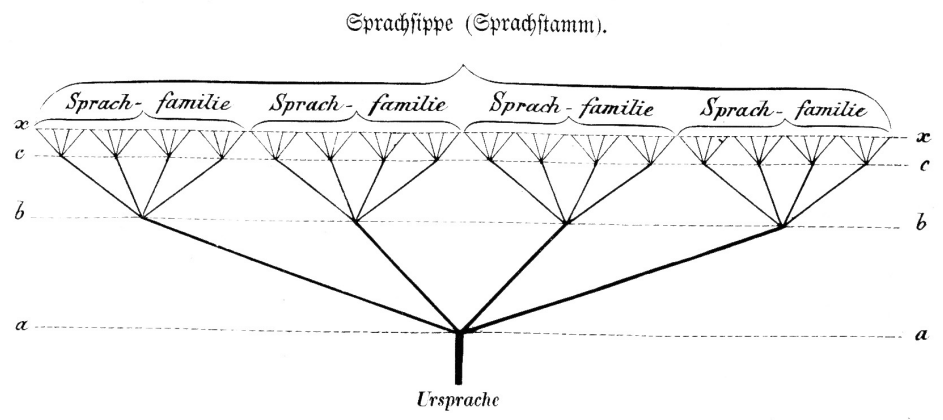

Figure 1. An ideal language family tree (Sprachsippe or Sprachstamm) after Schleicher 1860. 


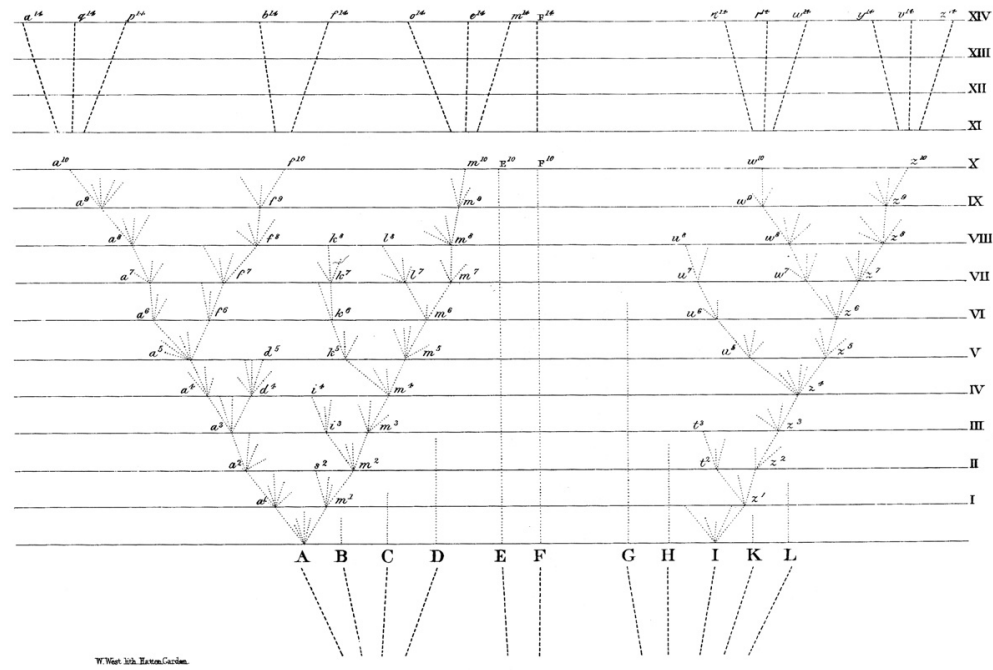

Figure 2. The only tree diagram in Darwin's On the Origin of Species after Darwin 1859.

title by hand "... and to the wife with an invitation to tea this evening". As a supplement to this book Schleicher presented a highly detailed family tree of Indo-Germanic languages. Schleicher and Haeckel were close friends, who worked together in Jena and influenced each other (see also Plank 1992: 107-109). Schleicher encouraged Haeckel to draw and promote the evolutionary tree, and the latter thanked him for the circular in the chapter Dualism and Monism (Haeckel 1866: 105-106) of the book General Anatomy of Organisms (1866).

But let us now return to the question whether Schleicher's theory was influenced by Darwin. Besides an ideal tree, Schleicher's book German Language (1860) presented three more separate language family trees for Lithuanian, German and Indo-Germanic proto-languages. In his open letter to Haeckel, Schleicher claimed that he was not familiar with the English original of Darwin's On the Origin of Species, which was published in November 1859. On Haeckel's recommendation, he allegedly read On the Origin of Species only in Heinrich Georg Bronn's German translation (Darwin 1860; after the 2nd edition 
of the original), which, according to Schleicher, contained amazing coincidences with his own German Language (1860). Bronn himself had published a tree of life (Fig. 3), which he called the branching of a system or organisation, well before Darwin's The Origin was published. A system has branches and boughs; the higher branches of the system appear evolutionally later (Bronn 1858: 481-482).

The current knowledge does not enable us to decide whether Darwin's On the Origin of Species, either the English original or the German translation, indeed has any impact on Schleicher's language family tree. The myth about Darwin's influence was spread later, primarily by Haeckel who was a keen promoter of Darwin and Darwinism. Robert J. Richards suggested that Darwin's impact on Schleicher could have been limited to the fact that as Darwin believed in progress, Schleicher in his book Darwin's Theory and Linguistics (1853) abandoned the idea of the decline of languages (Richards 2002: 40).

It is interesting to point out that Schleicher drew his first language family trees already in 1853 when he worked at the Prague university. Darwin's impact was then excluded. On 6 June 1853, Schleicher delivered a lecture at Prague university in Czech titled Lithuanian Language, where he described the division of the Slavo-Germanic branch of Indo-Germanic languages (Fig. 4) (1853a: 331). Within the same year he published a brief summary of the

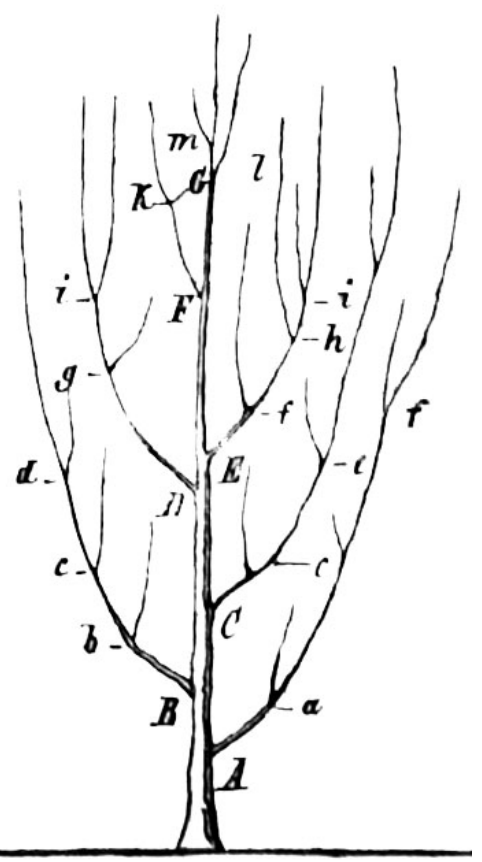

Figure 3. A tree of life (the branching of a system or organisation) after Bronn 1858. 


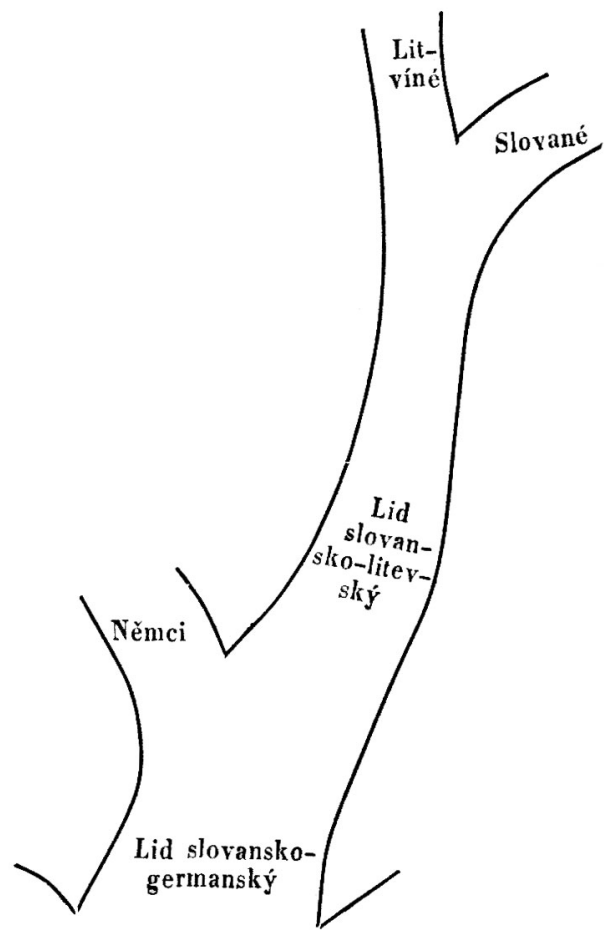

Pralid indogermanský.

Figure 4. Slavo-Germanic branch of the Indo-Germanic proto-branch after Schleicher 1853a.

same article in German, adding an illustration of the branching of the Indo-Germanic language tree (Fig. 5). Schleicher already used the term "tree" - sich verästelnder Baum - although not yet the term Stammbaum (1853b). It should be mentioned here that Schleicher used the term language family tree (Stammbaum $=$ stem tree) for the first time as early as in 1850 in European Languages (see Schleicher 1850: 22-25 and 30). This book does not depict a language family tree visually.

The issue of Schleicher's originality once again now emerges, because the same year he published his tree figures, a draft of a family tree of Slavic languages (Fig. 6) drawn by his 


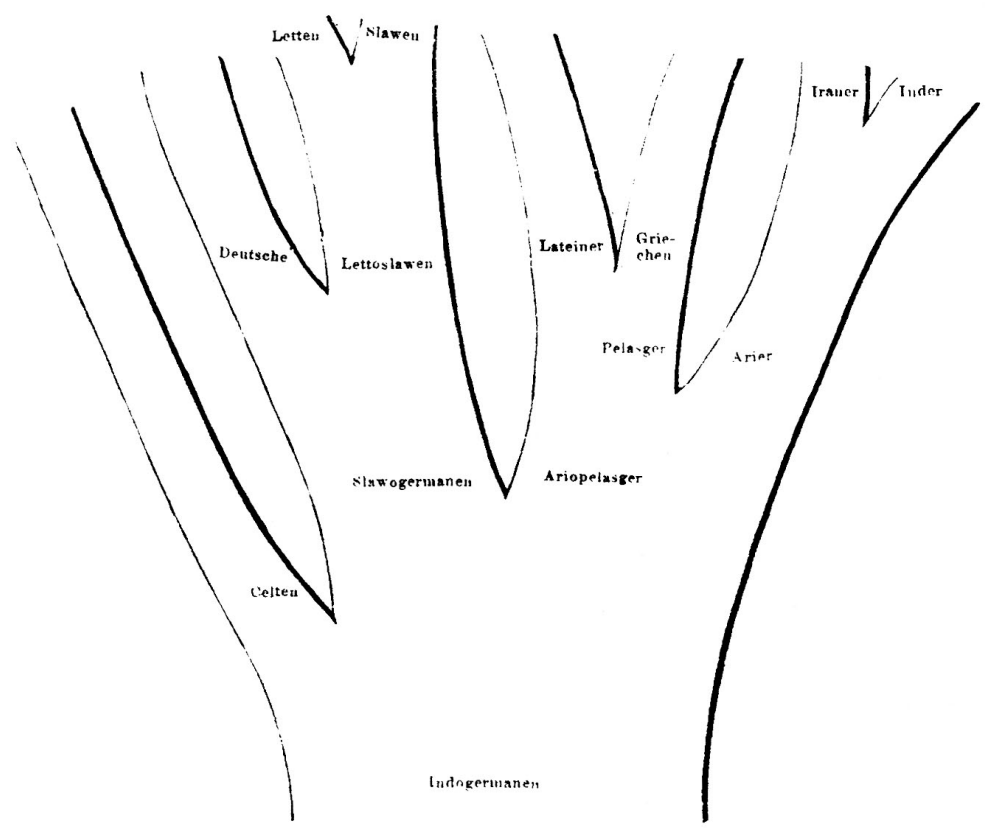

Figure 5. The first splits of the Indo-Germanic protopeople - self-branching boughs of a tree after Schleicher 1853b.

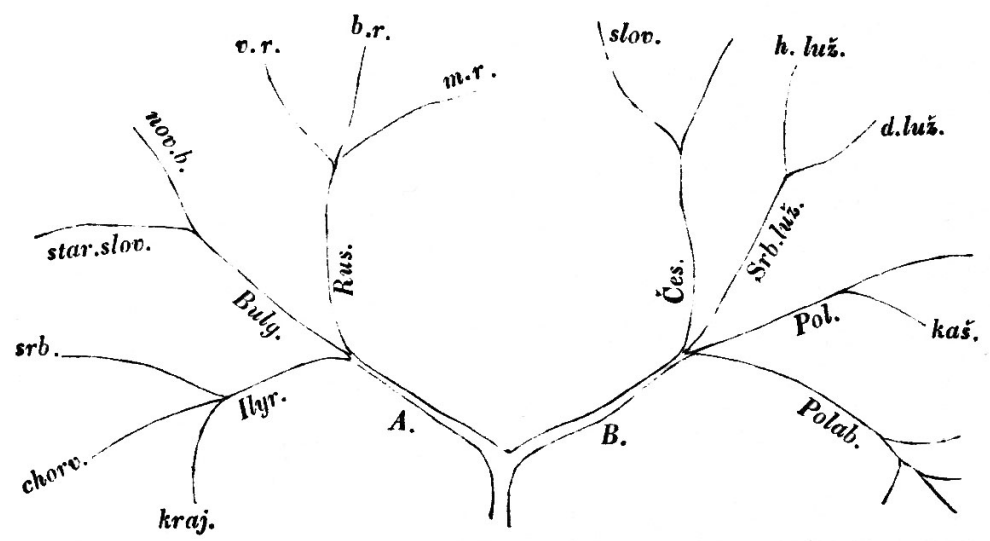

Figure 6. A Slavonic language family tree sketched in 1852 after Čelakovský 1853. 
colleague, František Ladislav Čelakovský (1799-1852), was posthumously published in Prague (1853: 3). It was probably compiled in 1852 (see Priestly 1975), and it was likely that Schleicher was familiar with it.

The real influence of Čelakovský and Darwin on Schleicher needs more thorough investigation. It is however obvious that Schleicher had a great impact on Haeckel who liked to draw and paint. His abundant development trees, sometimes called bushes, are well known (see Oppenheimer 1987). On the one hand, Haeckel derived inspiration from Darwin's diagram and the metaphor of the tree of life, and on the other from Schleicher's theory of the language family tree and the language trees. Haeckel identified races and languages (see his language and race trees). According to Schleicher, however, races and languages developed independently. Language family tree cannot therefore exactly correspond to human family tree. Haeckel, however, seemed to identify languages and their bearers. He even went as far as to distinguish between four human families (Gattung), twelve species (Art/Spezies) and thirty six human races (Fig. 7) (e.g. Haeckel 1920).

The idea of connecting languages and human classification on a contemporary level was again introduced in the groundbreaking article "Reconstruction of human evolution: bringing together genetic, archaeological, and linguistic data" (1988) by Luigi Luca Cavalli-Sforza and his colleagues.

\section{Darwin's tree diagram and metaphor of the tree of life}

Darwin's tree diagram is rather dry and schematic, whereas his description of the great tree of life is quite poetic. He wrote that "The affinities of all the beings of the same class have sometimes been represented by a great tree. I believe this simile largely speaks the truth. The green and budding twigs may represent existing species; and those produced during former years may represent the long succession of extinct species. ... As buds 


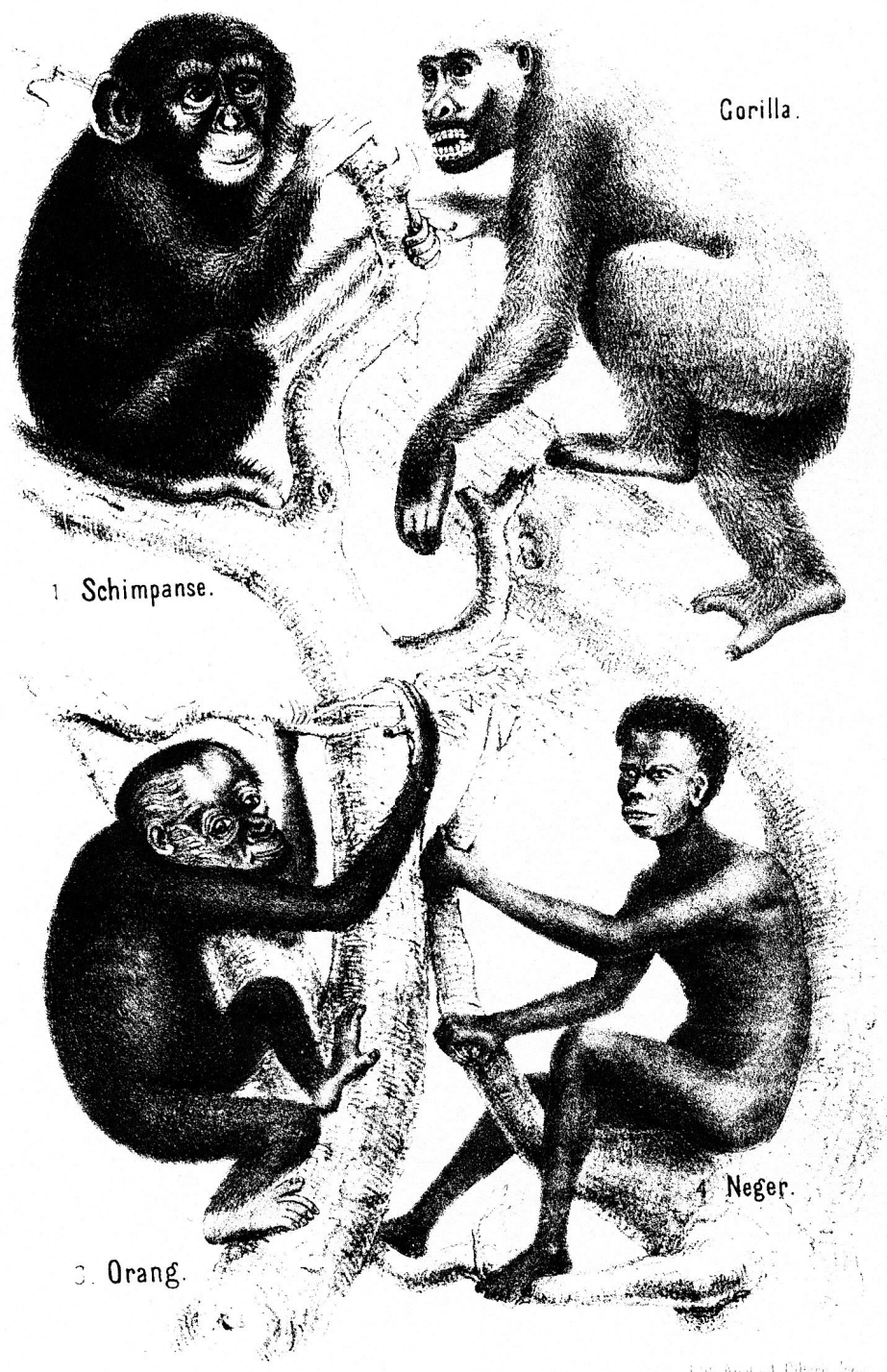

Figure 7. Part of the human family tree after Haeckel 1920. The ideas of Haeckel were one of the sources of the racial theories of the Third Reich. 
give rise by growth to fresh buds, and these, if vigorous, branch out and overtop on all sides many a feebler branch, so by generation I believe it has been with the great Tree of Life, which fills with its dead and broken branches the crust of the earth, and covers the surface with its ever-branching and beautiful ramifications" (Darwin 1859: 129-130).

What interests us in this description of a tree of life is Darwin's admittance that the affinity of organisms is sometimes shown as a tree of life, although he does not refer to anyone specific. In the chapter "Natural Selection" in his book "The Origin of Species", Darwin described the diagram of divergence without mentioning the tree of life, tree model or tree metaphor (see Darwin 1859: 116-117 and the relevant diagram). However, in the summary of the same chapter he described the tree of life on two pages, as if the tree and the diagram of divergence had nothing to do with one another.

The genesis of Darwin's tree diagram and the metaphor of the tree of life can be followed on the basis of his notes from 1837 onwards (Darwin 1987: 177 and 180; Notebook B26 and B36 respectively). The source of Darwin's tree of life has traditionally been seen in the heated discussions about the dichotomous method that raged in England between 1826 and 1830 (see e.g. the comments to the publication of Darwin's notes (Darwin 1987)).

At the Linnean Society of London, J. E. Bicheno presented a theoretical paper in 1826, titled "On systems and methods in natural history", which was published next year (1827). John Fleming replied to this with a critical article in the journal "The Quarterly Review" (1829), although he published it anonymously. Fleming wrote that in Linné's dichotomous system, class can be compared with a tree trunk, the lower stages or sections with branches, and the species with buds or leaves on the branches (Fleming 1829: 311). Fleming's review was fiercely opposed by William Sharp MacLeay in several issues in the journal "Philosophical Magazine" (1830).

MacLeay wrote that he published Horce Entomologica (1819), but the whole print run was unfortunately destroyed in fire. Only 80 copies had been circulated before the accident. 
MacLeay accused Fleming of poaching most ideas from him, including the image of the tree and the dichotomous model. He claimed that page 134 of the lost work had, for example, a sentence about dichotomous trees: "En, naturce arboris dichotomi corpora omnia proferentis terrestria organica ex ramusculis extremis aspicias unum!" According to MacLeay, the main idea of his book was to show the branching of a dichotomous tree. For him, such a tree meant a binary, organised division into animals and plants. The tree, however, is not branching endlessly (1830: 443). Some places in the article indicate that his idea might have originated from porphyric trees known in philosophy.

\section{Estonian traces}

Let us now take a look at Estonian links regarding the creation of theories about trees of life and language family trees. Peter Simon Pallas, for example, wrote in 1766, "the system of organic bodies is best presented with the image of a tree" (At omnium optime Arboris imagine adumbraretur Corporum organicorum Systema) (Pallas 1766: 23). Unfortunately, Pallas did not realise his idea in drawing a tree, but merely described it (id. 2324). The ideas of Pallas were developed further by a Baltic-German paleontologist from Coulrand, Karl Eduard von Eichwald, who studied and worked in a short period in Tartu. ${ }^{1}$ His tree of animal life diagram - Arbor vitae animalis - was the first depiction of the Palla's description of an imaginary tree of organic bodies (Fig. 8) (Eichwald 1829: table between pages 40 and 41, text $§ 63$ Arbor vitae animalis p. 41 ff.; cf. Ragan 2009: 5).

1 Karl Eduard Eichwald (1795-1876) studied medicine in Tartu University (1814-1817) and worked shortly (1821-1823) as a Privatdozent (Private lecturer) in Tartu. In 1822 autumn he read first paleontology course - oryctozoology in Tartu. Next year he had a ornithology course on Estonian, Livonian and Curonian birds. He was professor of zoology in Kazan, professor of zoology and comparative anatomy in Vilnius, professor of zoology, mineralogy and medicine, and finally professor of palaeontology in St. Petersburg. 


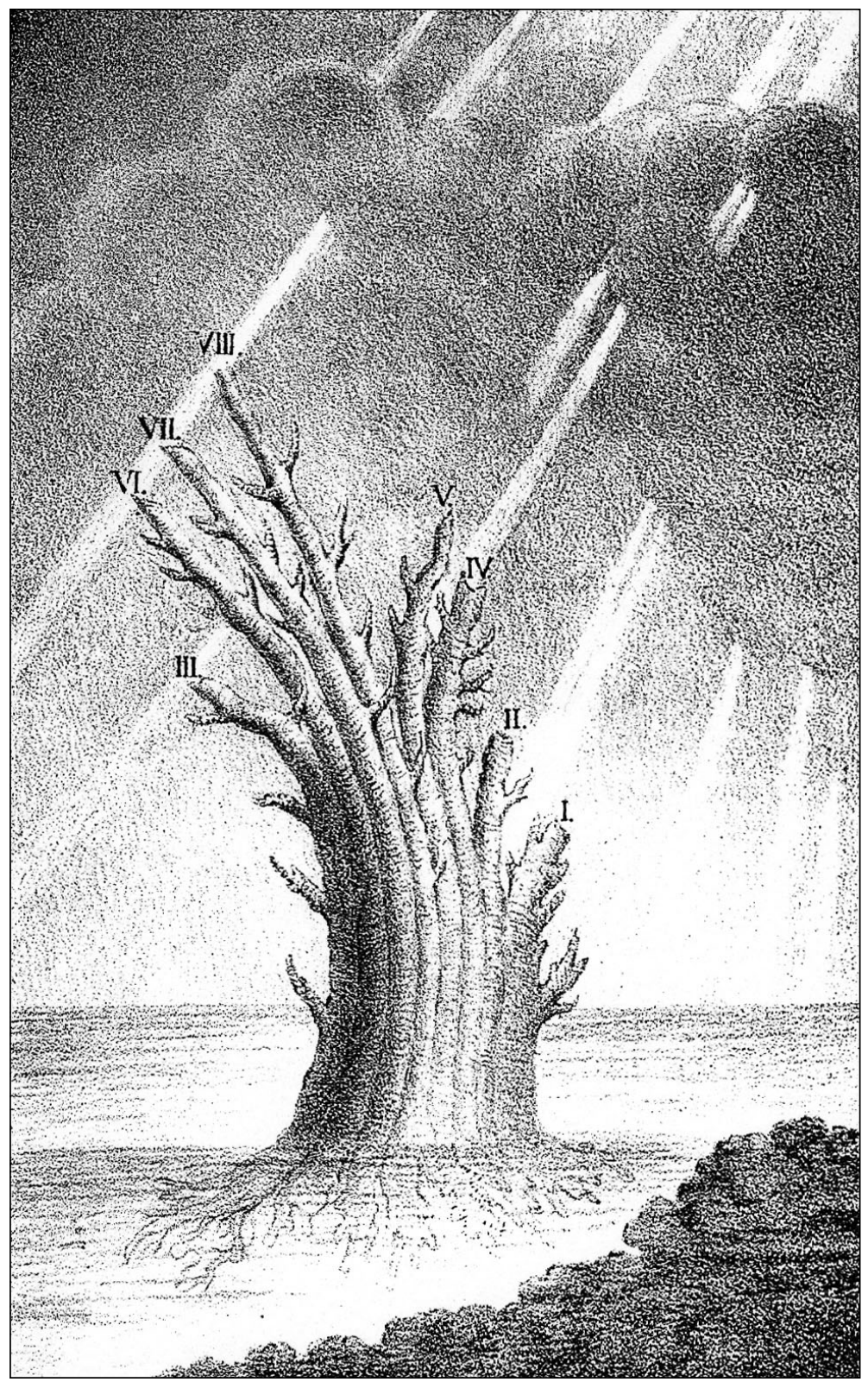

Figure 8. Tree of animal life - Arbor vitae animalis - a polyphyletic diagram after Eichwald 1829. 
Eichwald was quite critical to the former scholars who supported the idea of scala naturae or with his own words the idea of rerum naturae scala. He argued that the scale model represents all animals in a series (chain) from the simplest to the highest organisms (1829: 20-21). He divided all bodies into organic and inorganic ones. He held that the organic life (vita organicae) is diverse, chaotic and rudimentary. For systematising the organic life he divided it in one side into general and special and in the other side into animal life (vita animalis) and vegetal life (vita vegetabilis). He pictured the animal life as polyphyletic tree with unclear roots and eight stems or branches, i.e. animal life types - Spondylozoa, Podozoa, Taxozoa, Heterozoa, Therozoa, Grammozoa, Cyclozoa, and Phytozoa. In a strict sense this is not a tree model for there are many roots and eight stems staying tightly next to each other in the tree figure. It is rather forest or net model.

Steven Jay Gould was unrightfully critical to the Eichwald's ideas. He used Eichwald as an example of the creationist biologist. According to Gould the Eichwald's tree of life is a pre-evolutionary tree with biblical roots. He even held that while the eigth brances maintain their indepence right down to the base of the tree, it shows the created origin for easch separate type (Gould 1997: 31 and 33).

Michael Ruse pointed out that in 1837 the Scottish doctor Martin Barry published a family tree of animals to illustrate Estonian nobleman and scholar Karl Ernst von Baer's theory of embryology connections between the archetypes of animals (Ruse 1996: 111). Ruse concluded that it was not known whether Darwin was familiar with Barry's work and that Barry's tree in no way supported evolution. If we compare Barry's tree (Fig. 9) with Darwin's sketches of the same year, we see that Darwin's second sketch of the tree of life (B36) (Fig. 10) has certain similarities with Barry's tree. A highly significant detail is the number "1" placed next to the root of each tree. This was already pointed out by Robert J. Richards (1992: 111). It is also remarkable that Darwin sketched his first trees in the same year, in 1837. Darwin started his diary B in July 1837, whereas Barry's article 
appeared in April. Richards claimed that Darwin had read the article shortly before he sketched his own tree of life (2009: 416). Barry's animal tree stands out for its three dimensions (compare the dotted lines depicting birds and reptiles). Barry's tree sketch presents Baer's four archetypes and the corresponding development formations (Richards 1992: 111). Richards is also of the opinion that Darwin's tree is homologous with Barry tree, ad-

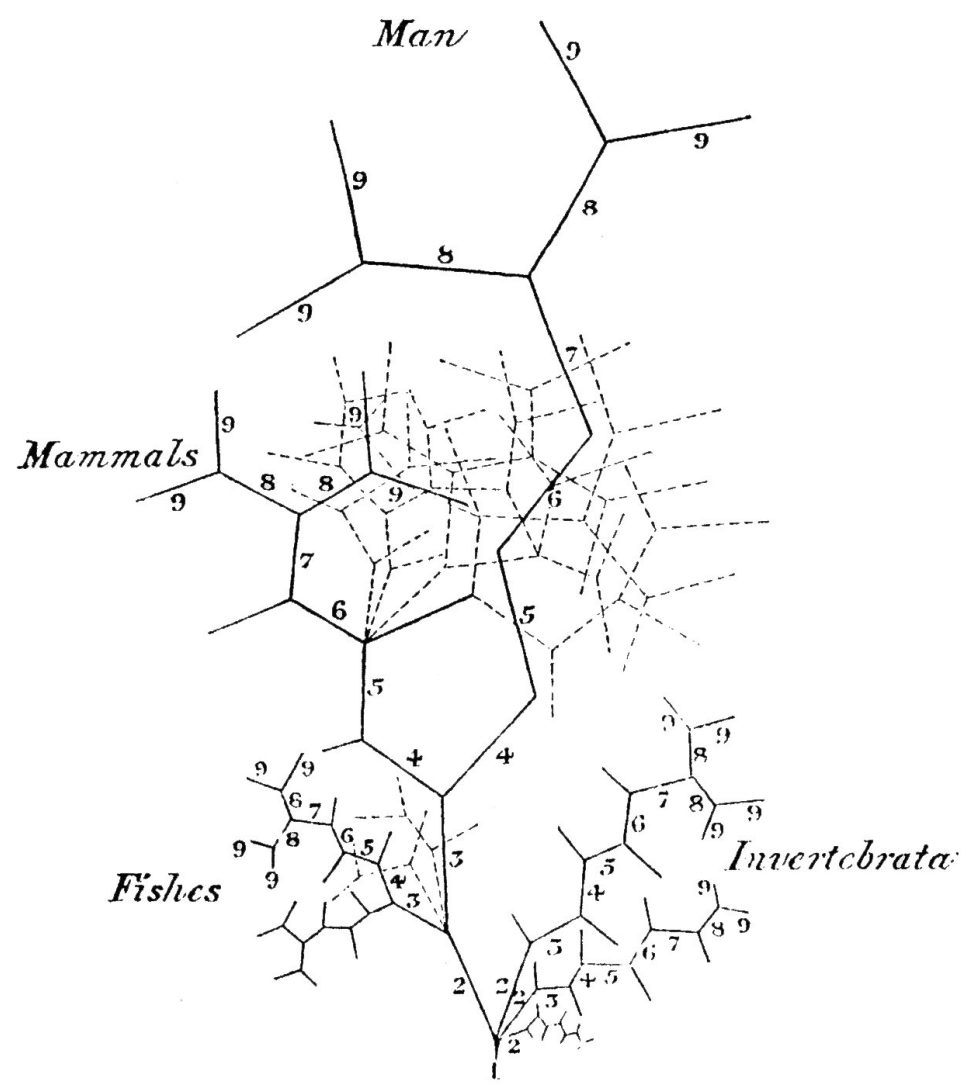

Figure 9. The tree of the development of the whole animal kingdom that illustrates Karl Ernst von Baer's ideas on four archetypes and the corresponding development formations after Barry 1837. 


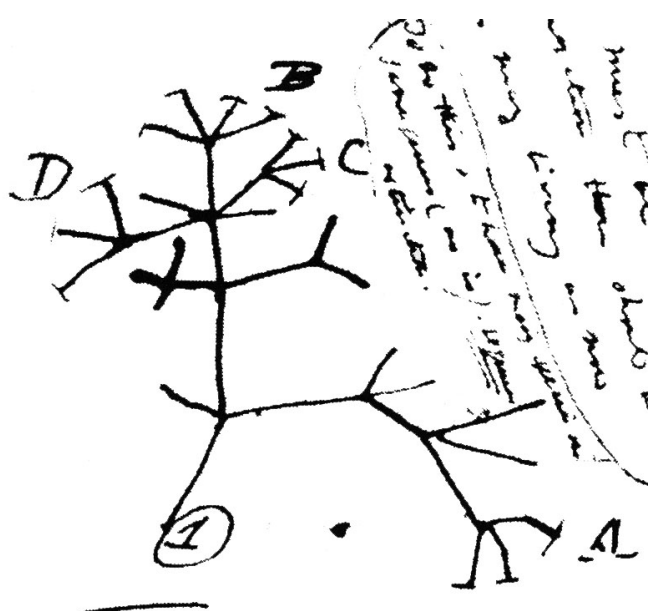

Figure 10. Darwin's second sketch of the tree of life (B36) which shows some similarities with the Barry's tree.

ditionally pointing out that Darwin noted near his drawing that families may emerge - bearing relation to ancient types.

Ruse has indicated that Barry's tree does not show evolution, i.e. the origin. Looking at Barry's arguments, we see that according to him:

1) Heterogeneous or special structure arises only out of one more homogenous or general, and this is by a gradual change.

2) The manner of the change, is probably the same throughout the animal kingdom.

3) The direction (or type) and degree of development can differ, and thus produce a variety in structure.

4) Which is in essential character, fundamentally the same.

5) No two individuals can have precisely the same innate susceptibilities of structure, or plastic properties.

6) Therefore, all the individuals of a species, may take, in their development, the same general direction, there is a particular direction in development and therefore a particular structure proper to each individual. 
7) Structures common to a whole class must, in a modified form, reappear in individual development.

8) They can reappear in certain order only (in the order of their generality) (Barry 1837: 345-346).

Barry's diagram - the animal development tree - was meant to illustrate these eight conclusions. Barry wrote that the question whether there was a scale of structures in the animal kingdom that would differ only by degree, was incorrect. We have to "distinguish between the degree of elaboration and the type of structure". In a footnote, Barry added that the quotation was from von Baer (Von Bär) (Barry 1837: 347). We can conclude that although Barry called his diagram a tree of development and gave it the relevant shape, it was essentially still a scale or scala naturae. (Lamarck's scala naturae was already a tree model, because it contained genealogical relations between the "stages" of the ladder.)

The numbers in Barry's tree should be read as follows:

1) No appreciable differences in the Germs of all animals (Fundamental Unity?).

2) The Class manifest, but the Order not distinguishable.

3) The Order obvious, but not the Family.

4) The Family manifest, but the Genus not known.

5) The Genus obvious, but not the Species.

6) The Species manifest, but the Variety unpronounced.

7) The Variety obvious, but Sexual difference scarcely apparent.

8) The Sexual character obvious, but the Individual character obscure.

9)The Individual character in its most special form.

Barry's diagram can be compared with Baer's table of classification, "The idea of developmental improvements" in his book Developmental history of animals: observation and reflection (1828). The table was added to page 225 of the first volume of the book. Despite minor differences, it is possible on the basis of this table to construct a similar tree, which Barry probably did. We should also point out that in his article Barry discusses the very same book by Baer. It should not be forgotten that Bar- 
ry was probably familiar with discussions about dichotomous method and the tree metaphor mentioned there.

Darwin studied Baer's works more thoroughly after 1853, when he read Thomas Henry Huxley's selected translations from Baer's already mentioned work Entwickelungsgeschichte (Baer 1853). Page 215 of the English version presents the classificatory scheme of developmental progress (Baer at 1828: 225), which is easy to adapt into a tree. Either in the same year of 1853 or next year, Darwin sketched an archetypal evolutionary tree (Fig. 11) on the basis of Baer's developmental theory (see Richards 1992: 140 ff.).

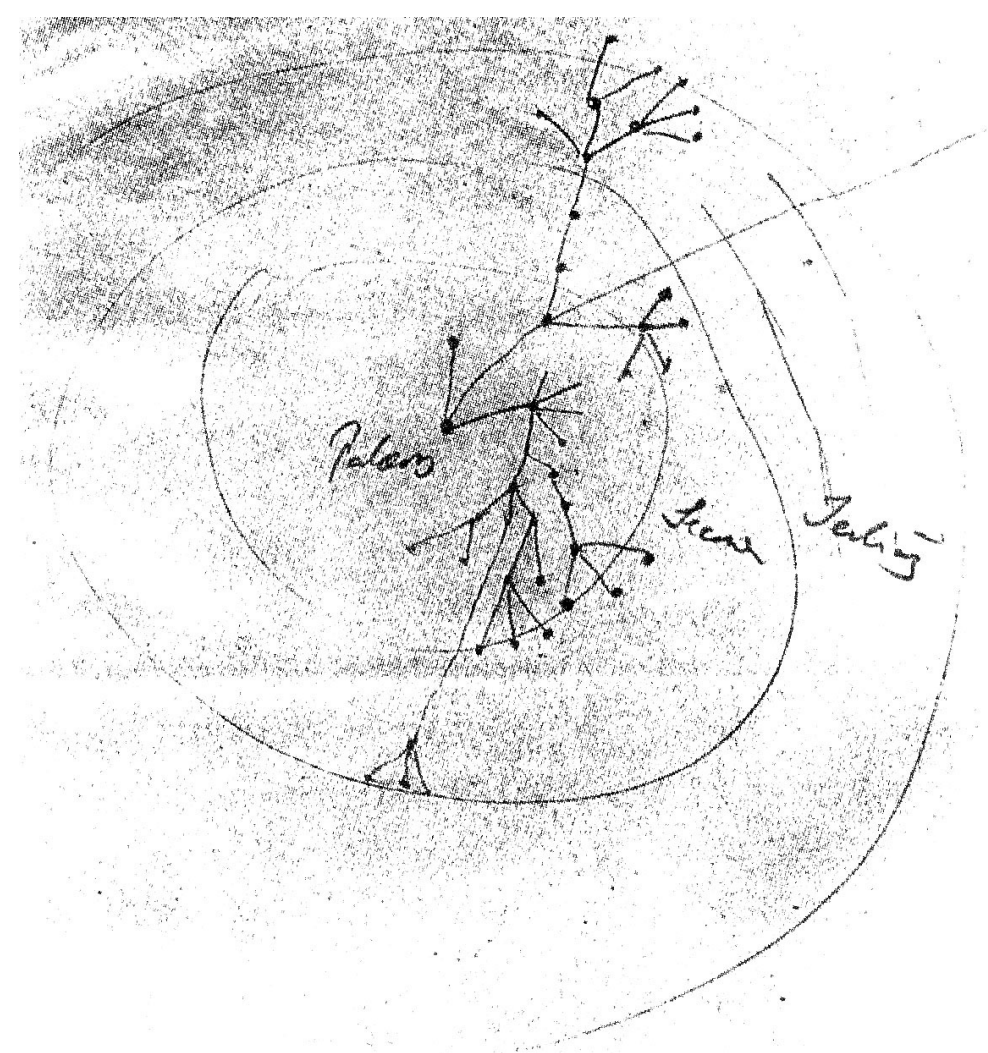

Figure 11. Darwin's archetypal evolutionary tree sketch (1853) on the basis of Baer's developmental theory after Richards 1992. 
We can thus claim that Baer's dichotomous classificatory table of developmental improvements is one source of Darwin's tree of life metaphor and the tree diagram, firstly through Barry's (1837) work and drawing, and later directly, after studying the translation of Baer's book.

Baer commented on Darwin's tree diagram, without directly naming it, in his work Teaching of Darwin (Baer 1876: 291). $\mathrm{He}$ wrote that if different species endlessly variegated and the variation proceeded into diverse directions, the result would be chaos without firm forms, which we call species. However, if for example in the course of 100 generations (or 1000 or 10,000 generations, according to Darwin), form $\mathrm{x}$ goes through a significant modification, with the subsequent different lines of descendants, it emerges at different times. If we mark the different degrees of modification of form $x$ with $a, b, c$ etc., then we at the same moment get $x c, x b$ or $x d$. The more often the modifications are repeated, the more unequal become the degrees of development. In that case, the degree of development xcc occurs simultaneously not only with xbb, but also with xcacdcf, etc. There must be all kinds of transitions. Nature, however, does not work like this. As we can see, Baer rejects Darwin's tree model that shows evolution, which had been inspired by his own classificatory table.

On the other side, James Allen Rogers has pointed out that "although von Baer resolutely opposed the [Darwin's] theory of natural selection, his own writings often showed him to be more of a Darwinist than he realized. Von Baer had suggested the probability that related forms of animals were descended from a common form" (Rogers 1973: 491).

The first language family trees I managed to track down date from the 17 th century. To my knowledge, the very first language family tree (Fig. 12) was published by the EstonianSwedish scholar Georg Stiernhielm ${ }^{2}$. He presented a hypothetical

2 Georg Stiernhielm (1598-1672) was a lawyer, linguist, mathematician, physicist, philosopher, astronomer, royal poet at the court of Queen Christina, etc. Between 1630 and 1656, worked at the Court of Appeal in Tartu, became its vice-president; was not directly connected with the Tartu academe. 


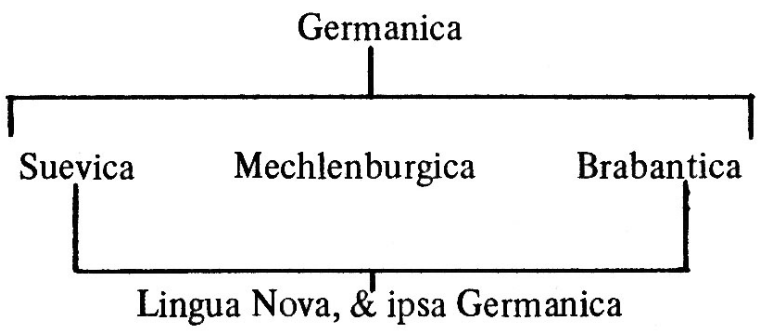

Figure 12. An early tangling, i.e. not-well-formed language family tree after Stiernhielm 1671.

language family tree in the introduction to the edition of Wulfia's Gothic Bible (1671: xxxi-xxxii). He suggested that three Germanic dialects can gradually merge into one new dialect, which would be different from the earlier ones, but would still be a Germanic dialect - Lingua Nova, \& ipsa Germanica. Strictly speaking, this is not in fact a tree model, as its branches cross and merge.

\section{Earlier language and evolutionary trees}

Besides Georg Stiernhielm's language family tree, there are other much earlier trees than Čelakovskýs and earlier evolutionary trees than Darwin's. In 1800, Felix Gallet produced a language tree (Fig. 13) - The Genealogical Tree of Living and Dead Languages (Arbre Généalogique des langues mortes et vivantes) (see Auroux 1990: 229). The data used in drawing the tree were largely outdated even back then. All European languages, for instance, originated from Celtic. On the other hand, the tree contains features well ahead of their time (just like Stiernhielm's tree), only recently rediscovered. The genealogical tree's living and dead languages namely have more than one direct predecessor. French, for instance, emerged as a result of crossing Old Germanic (Frank) and Romance languages. In that sense it is clear that Gallet's tree as a tree model is actually incorrect. Schleicher, too, allowed for the possibility that the 
Romance languages emerged after several crossings (1863: 17). The Genealogical Tree of Living and Dead Languages has similarities with the botanic tree Arbre botanique drawn by Augustine Augier (1801) (Stevens 1983. 204).

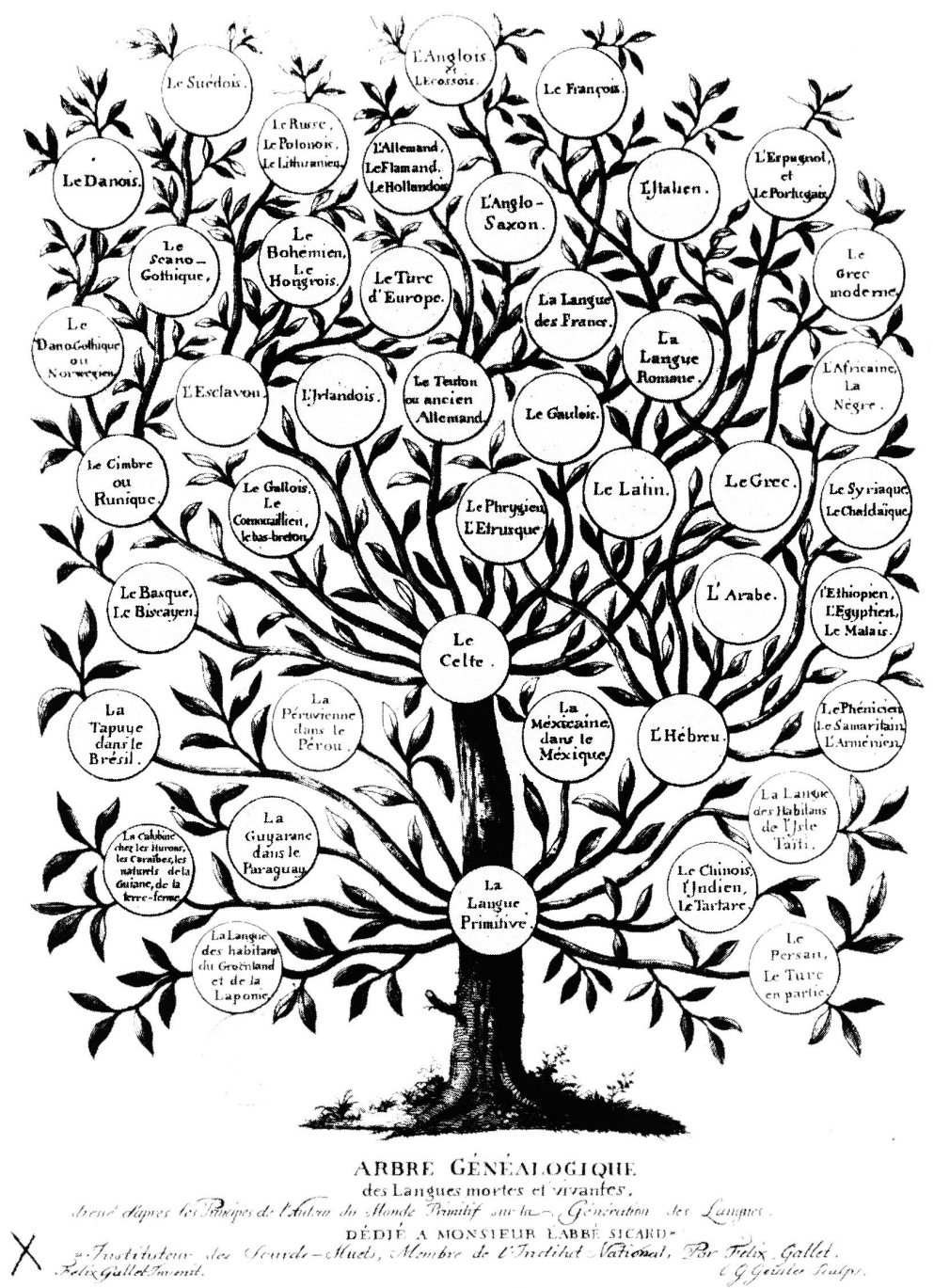

Figure 13. An early tangling language family tree compiled by Felix Gallet about 1800 after Auroux 1990. 
In addition to Georg Stiernhielm's language family tree, the 17th century offers another language family tree and a description of a situation resembling Stiernhelm's. In the year when Stiernhielm published his language family tree, Stephen Skinner (1671: ii) described a situation where three English speakers find themselves on a desert island. The Londoner speaks an educated language, whereas two countrymen, one from Devonshire and the other from York, do not. They have difficulties understanding one another. As time passes, two possibilities emerge: either the countrymen learn to speak like the man from a big city, or an altogether new language will develop - una lingua ex tribus mixtis \& simul contemperatis conflata. A few decades later Georg Hickes presented a diagram of the origin of Gothic (Germanic) languages (1689: xiv), which perfectly corresponds with the tree model (Fig. 14).

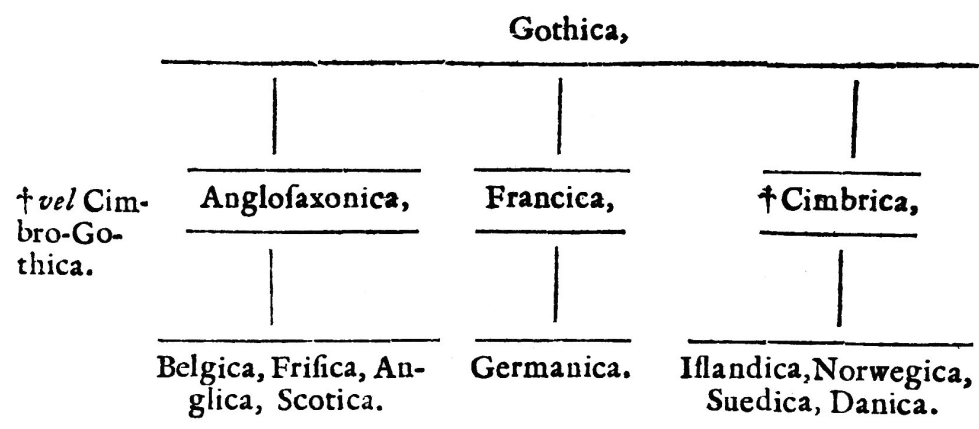

Figure 14. An early language family tree after Hickes 1689.

Coming back to evolutionary trees, we should mention Jean-Baptiste Lamarck's "Table of origin of various animals" (Fig. 15) in the second part of his book Zoological Philosophy (1809: 463). It is interesting to see that although Lamarck talks about the origin of different animals, his comments indicate as if his table were scala naturae - une l'echelle animale (Lamarck 1809: 462). Unlike Barry's evolutionary tree, which was called a tree although it was essentially a scale, here everything is the other way round. Lamarck presents a scale, but essentially it is a tree showing connections of descent. In order to differentiate his 
318 Urmas Sutrop

\section{'T A B L E A U}

Servant à montrer l'origine des différens animaux.

Vers.

Infusoires.

Polypes.

Radiaires.

Annelides.

Insectes.

Arachnides.

Cirrhipèdes.

Crustacés.

Mollusques.

Poissons.

Reptiles.

Oiseaux.

Monotrèmes.

M. Amphibies.

M. Cétacés.

M. Onguiculés.

M. Ongulés.

Figure 15. Table (tree) of origin of various animals - une l'echelle animale after Lamarck 1809.

scale from all other scales of the time without connections of descent. Lamarck turned his scale upside down: he placed higher animals on lower scales and less developed animals higher up. 
See also Archibald (2009) about pre-Darwin biological and geological tree models

The Aristotelian idea of scala naturae has its metaphoric roots in the First Book of Moses (28: 12):

And he [Jacob] dreamed, and behold a ladder set up on the earth, and the top of it reached to heaven: and behold the angels of God ascending and descending on it.

Hence calling scala naturae Jacob's ladder (Fig. 16). It is sometimes also called the great chain of being (compare Lovejoy 1936). In biology, scala naturae achieved perfection in the works of Charles Bonnet's works. We are not going to examine the scales here in great detail, but merely point out that they were often depicted as trees, although we cannot regard them as tree models, because there were no connections of descent between the scales. Umberto Eco also noted that for example Raymond Lull's The Tree of Knowledge from 1296 perfectly corresponded to the idea of the great chain of being (Eco 1995: 66-67). Natural

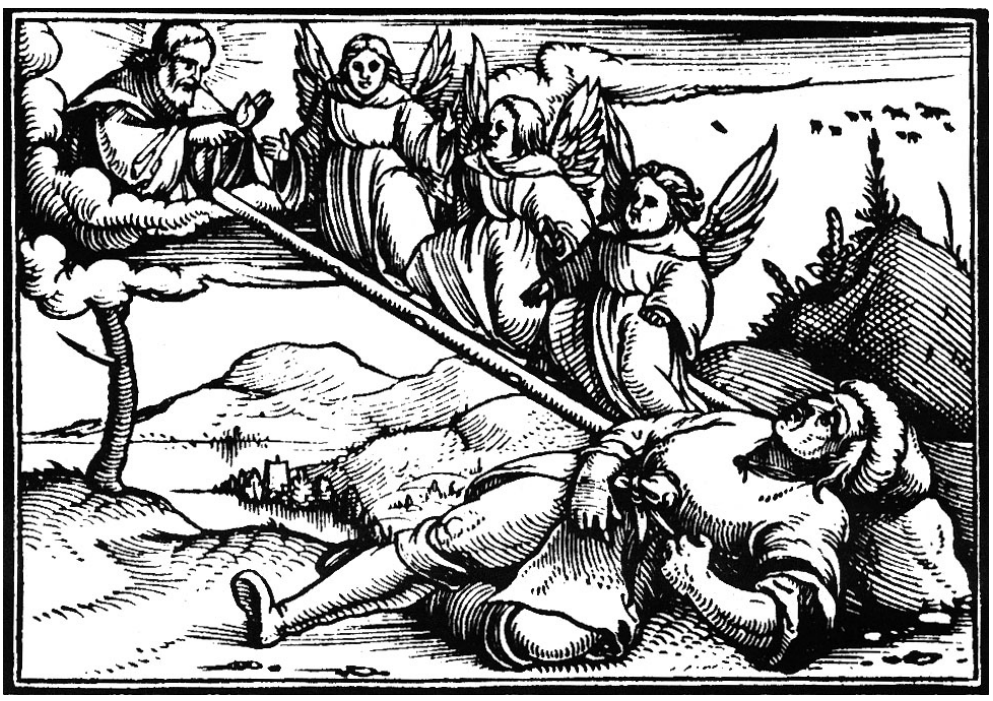

Figure 16. Jacobs ladder after Zürcher Bibel 1531. 
scales start with fire, water, earth and air, and human beings, typically, are placed on the one but last step of the ladder, or on the last but three. It depends on whether there are angels between men and God or not.

\section{Conclusion}

The requirements set to the tree models - each tree has only one root and the branches should not cross - cause problems in linguistics. The past decades have increasingly focused on language contacts. It has become clear that languages have many roots, and many features overlap and blend. It is sensible here to analyse Anthony Fox's scheme Sources of Contemporary English. His scheme does not quite correspond to the tree model, as numerous branches overlap and cross.

R. M. W. Dixon (1997) used the model of punctuated equilibrium in language family trees (Eldridge and Gould 1972, Gould and Eldridge 1993). However, if we take a closer look at it, we see that the new tree (new trees) emerging after the balance was disrupted can have several roots. This is thus a web model.

It must therefore be admitted that the language family tree model in contemporary linguistics is primarily a metaphor, which could have a vastly different content. Language models have great didactic value. They show simplified connections of descent, but ignore language contacts and exchanges.

Besides tree models, biology, too, uses other models and metaphors. Daniel Dennett - depicted a tree of life as a palm tree, where the trunk is a pseudostem. If we take a magnifying glass to this tree, we would see that each branch consists of numerous smaller and thinner branches. Through a microscope we finally see the trajectories of individuals. Some get disrupted, some continue. The trajectories of multisexual organisms cross and at this kind of magnification they form a web (Dennett 1996: $85 \mathrm{ff}$.). The idea of a similar web already occurred in the works of Willi Henning, creator of contemporary cladistics. Henning 
(1950) points to Danser's (1924: 269) web of the crossing of Rumex species. As early as 1755, Buffon depicted the relations between dog breeds as a diagram that took shape via crossings (Buffon 1775: folded sticker in Table de l'Ordre des Chiens, between pages 228 and 229).

The endosymbiotic theory has also introduced new development models. Talking about earlier stages of life, the tree of life has been replaced by the tangled web of life (Katz 1998).

A befitting conclusion here would be an idea expressed by Kalevi Kull: during the pre-modern history, science used the holistic ladder model, in modern history it used the tree model, and today's (postmodern) science prefers a more semiotic web model to the tree model (Kull 2003).

The web metaphor is currently the best, which the linguists could take over from biologists. The web model and metaphor enable to better depict the connections between languages, consider influences, loans, contacts with other languages, and the phenomena of substrate, superstrate or adstrate.

\section{Acknowledgements}

I thank Ms. Tiina Randviir, Estonian Institute, Tallinn, for reading the manuscript and translating it into English. I also thank Dr. Mari Uusküla for reading and commenting the manuscript. The work was supported by the Estonian Ministry of Education and Research project no SF0050037s10 and Estonian Science Foundation grant no 6744.

\section{Address:}

Urmas Sutrop

Institute of the Estonian Language

Roosikrantsi 6

10119 Tallinn, Estonia

E-mail: Urmas.Sutrop@eki.ee 


\section{References}

Archibald, J. David (2009) "Edward Hitchcock's Pre-Darwinian (1840) 'Tree of life"". Journal of the History of Biology 42: 561-592.

Auroux, Sylvian (1990) "Representation and the place of linguistic change before comparative grammar". In Tullio de Mauro and Lia Formigari, eds. Leibniz, Humbolt and the origins of comparativism, 213-238. (Studies in the History of the Language Sciences, 49.) Amstedam and Philadelphia: John Benjamins Publishing Company.

Baer, Karl Ernst von (1828) Entwickelungsgeschichte der Thiere: Beobachtung und Reflexion. Königsberg: Borntrager.

Baer, Karl Ernst von (1853) "Fragments relating to philosophical zoology: selected from the works of K. E. von Baer". Thomas Henry Huxley, transl. In Arthur Henfrey and Thomas Henry Huxley, eds. Scientific memoirs, selected from the transactions of foreign academies of science, and from foreign journals: natural history, 176-238. London: Taylor and Francis.

Baer, Karl Ernst von (1876) “Ueber Darwin's Lehre”. In his Reden, gehalten in wissenschaftlichen Versammlungen und kleinere Aufsätze vermischten Inhalts. Bd. 2. Studien aus dem Gebiete der Naturwissenschaften, 235-480. St. Petersburg: Karl Röttger.

Barry, Martin (1837) "Further observations on the unity of structure in Animal Kingdom, and on congenital anomalies, including 'Hermaphrodites;' with some remarks on embryology, as facilitating animal nomenclature, classification, and the study of comparative anatomy". Edinburgh New Philosophical Journal 22: 345-364.

Bicheno, J. E. (1827) "On systems and methods in natural history. Read June 4, 1826". The Transactions of the Linnean Society of London 1st Ser. 40: 479-496.

Bronn, Heinrich Georg (1858) Untersuchungen über die EntwickelungsGesetze der organischen Welt während der Bildungs-Zeit unserer Erd-Oberfläche. Eine von der Französische Akademie im Jahre 1857 gekrönte Preisschrift. Stuttgart: F. Schweizerbart.

Buffon, Georges Louis Leclerc de (1755) Histoire naturelle, generale et particuliere avec la description du cabinet du Roi. Tom 5. Paris: de l'Imprime Royale.

Cavalli-Sforza, Luigi Luca, Alberto Piazza, Paolo Menozzi, and Joanna Mountain (1988) "Reconstruction of human evolution: bringing together genetic, archaeological, and linguistic data". Proceedings of the National Academy of Sciences of the United States of America 85, 16: 6002-6006.

Čelakovský, František Ladislav (1853) Čtení o srovnavaci mluvnici slovanské na universitě Pražské. (Novočeská bibliotéka, 17.) Prague: F. Řivnáč.

Danser, B. H. (1924) "De nederlandsche Rumex-bastaarden. (Derde deel)". Nederlandsch Kruidkundig Archief, Jaarg. 1923, 232-270. Amsterdam: J. H. de Bussy. 
Darwin, Charles (1859) On the origin of species by means of natural selection, or the preservation of favoured races in the struggle for life. London: John Murray.

Darwin, Charles (1860) Über die Entstehung der Arten im Thier- und Pflanzen-Reich durch natürliche Züchtung, oder Erhaltung der vervollkommneten Rassen im Kampfe um's Daseyn. Nach der zweiten Auflage mit einer geschichtlichen Vorrede und andern Zusätzen des Verfassers für diese deutsche Ausgabe aus dem Englischen übersetzt und mit Anmerkungen versehen von Dr. H. G. Bronn. Stuttgart: Schweizerbart.

Darwin, Charles (1987) Charles Darwin's Notebooks, 1836-1844: geology, transmutation of species, metaphysical enquiries. Paul H. Barrett, Peter J. Gautrey, Sandra Herbert, David Kohn and Sydney Smith, transcr. and eds. London: British Museum (Natural History) and Ithaca, NY: Cornell University Press.

Dennett, Daniel C. (1996) Darwin's dangerous idea: evolution and the meanings of life. London: Penguin Books.

Dixon, R. M. W. (1997) The rise and fall of languages. Cambridge: Cambridge University Press.

Eco, Umberto (1995) The search for the perfect language. (The Making of Europe.) Oxford: Blackwell. (First Italian ed. Ricerca della lingua perfetta nella cultura europea, 1993.)

Eichwald, Eduard (1829) Zoologia specialis quam expositis animalibus tum vivis, tum fossilibus potissimum Rossiae in universum, et Poloniae in specie, in usum lectionum publicarum in universitate Caesarea Vilnensi habendarum. Pars prior. Propaedeuticam zoologiae atque specialem Heterozoorum expositionem continens. Vilniae: Typis Josephi Zawadzki.

Eldredge, Niels and Stephen Jay Gould. (1972) "Punctuated equilibrium: an alternative to phyletic gradualism". In Thomas J. M. Schopf, ed. Models in paleobiology, 82-115. San Francisco: Freeman, Cooper \& Company.

Fleming, John (1829) "[Unsigned response to] On systems and methods in natural history. By J. E. Bicheno, Esq. 1829. (Linn. Trans., xv., part 2.)". The Quarterly Review (London) 41: 302-327.

Fox, Anthony (1995) Linguistic reconstruction: an introduction to theory and method. (Oxford Textbooks in Linguistics.) Oxford: Oxford University Press.

Gould, Stephen Jay (1997) "Redrafting the tree of life". Proceedings of the American Philosophical Society 141, 1: 30-54.

Gould, Stephen Jay and Niels Eldredge (1993) "Punctuated equilibrium comes at age". Nature 366: 223-227.

Haeckel, Ernst (1866) Allgemeine Anatomie der Organismen. Kritische Grundzüge der mechanischen Wissenschaft von den entwickelten Formen der Organismen, begründet durch die Descendenz-Theorie. (Generelle 
Morphologie der Organismen. Allgemeine Grundzüge der organischen Formen-Wissenschaft, mechanisch begründet von Charles Darwin reformierte Descendenz-Theorie, 1.) Berlin: Georg Reimer.

Haeckel, Ernst (1920) Natürliche Schöpfungs-Geschichte: Gemeinverständliche wissenschaftliche Vorträge über die Entwickelungslehre. 12. verb. Aufl. Berlin und Leipzig: Vereinigung wissenschaftlicher Verleger Walter de Gruyter \& Co.

Hennig, Willi (1950) Grundzüge einer Theorie der phylogenetischen Systematik. Berlin: Deutscher Zentralverlag.

Hickes, George (1689) Institutiones Grammaticae Anglo-Saxonicae et M soGothica. Oxoniæ: Typis Junianis.

Hoeningswald, Henry M. (1987) "Language family trees: topological and metrical". In Henry M. Hoeningswald and Linda F. Wiener, eds. Biological metaphor and cladistic classification: an interdisciplinary perspective, 257-267. Philadelphia: University of Pennsylvania Press.

Katz, Laura A. (1998) "Changing perspectives on the origin of eukaryotes". Trends in Ecology and Evolution 13, 12: 493-497.

Kull, Kalevi (2003) "Ladder, tree web: the ages of biological understanding". Sign Systems Studies 31, 2: 589-603.

Lamarck, Jean Baptist (1809) Philosophie zoologique, ou exposition des considérations relatives à l'histoire naturelle des animaux. Tome 2 . Paris: Dentu.

Lovejoy, Arthur O. (1936) The great chain of being: a study in the history of idea. Cambridge, Mass.: Harvard University Press.

MacLeay, William Sharp (1830) "On the dying struggle of the dichotomous system". Philosophical Magazine 7: 431-431, 8: 53-57, 134-140 and 200-207.

Macleay, William Sharp (1919) Horce Entomologica: or essays on the annulose animals. London: S. Bagster.

Oppenheimer, Jane M. (1987) "Haeckel's variations on Darwin". In Henry M. Hoeningswald and Linda F. Wiener, eds. Biological metaphor and cladistic classification: an interdisciplinary perspective, 123-135. Philadelphia: University of Pennsylvania Press.

Pallas, Peter Simon (1766) Elenchus zoophytorum sistens generum adumbrations generaliores et specierum cognitarum succinitas descriptions cum selectis auctorum synonymis. Hagæ: Apud Petrum von Cleef.

Plank, Frans (1992) Wohl-geschliffener Tugendspiegel des Sprachforschers, demselben vorgehalten von einer Societät zur Beförderung der praktisch reinen Vernunftmoral. Münster: Nodus Publikationen.

Priestly, T. M. S. (1975) Schleicher, Čelakovský, and the family-tree diagram. Historiographia Linguistica 2-3: 299-333.

Ragan, Mark A. (2009) “Trees and networks before and after Darwin”. Biology Direct 4, 43: 1-38.

Richards, Robert J. (1992) The meaning of evolution: the morphological construction and ideological reconstruction of Darwin's theory. (Science 
and its Conceptual Foundations.) Chicago and London: The University of Chicago Press.

Richards, Robert J. (2002) "The linguistic creation of man: Charles Darwin, August Schleicher, Ernst Haeckel, and the missing link in 19th-century evolutionary theory". In Matthias Dörries, ed. Experimenting in tongues: studies in science and language, 21-48. (Writing Science.) Stanford: Stanford University Press.

Richards, Robert J. (2009) “The descent of man. [Book review on] Darwin's sacred cause: how a hatred of slavery shaped Darwin's views on human evolution. Adrian Desmond and James Moore. xxii + 485 pp. Houghton Mifflin Harcourt, 2009. \$30”. American Scientist 97, 5: 415-417.

Rogers, James Allen (1973) “The reception of Darwin's Origin of species by Russian scientists”. Isis 64, 4: 484-503.

Ruse, Michael (1996) Monad to man: the concept of progress in evolutionary biology. Cambridge, MA and London: Harvard University Press.

Ruvolo, Maryellen (1987) "Reconstructing genetic and linguistic trees: phenetic and cladistic approaches". In Henry M. Hoeningswald and Linda F. Wiener, eds. Biological metaphor and cladistic classification: an interdisciplinary perspective, 193-216. Philadelphia: University of Pennsylvania Press.

Schleicher, August (1850) Die Sprachen Europas in systematischer Uebersicht. (Linguistische Untersuchungen, 2.) Bonn: H. B. König.

Schleicher, August (1853a) "O jazyku litevském, žvlástě ohledem na slovanský”. Časopis Českého Museum (Prague) 27, 2: 320-334.

Schleicher, August (1853b) "Die ersten Spaltungen des indogermanischen Urvolkes". (Kieler) Allgemeine Monatsschrift für Wissenschaft und Literatur. September: 101-102 (786-787).

Schleicher, August (1860) Die Deutsche Sprache. Stuttgart: J. G. Cotta.

Schleicher, August (1861) Kurzer Abriss einer Lautlehre der indogermanischen Ursprache, des Altindischen (Sanskrit), Alteranischen (Altbaktrischen), Altgriechischen, Altitalischen (Lateinischen, Umbrischen, Oskischen), Altkeltischen (Altirischen), Altslawischen (Altbulgarischen), Litauischen und Altdeutschen (Gotischen). (Compendium der vergleichenden Grammatik der indogermanischen Sprachen, 1.) Weimar: Hermann Böhlau.

Schleicher, August (1863) Die Darwinsche Theorie und die Sprachwissenschaft. Offenes Sendeschreiben an Herrn Dr. Ernst Häckel, a. o. Professor der Zoologie und Director des zoologischen Museums an der Universität Jena. Weimar: Hermann Böhlau. (New ed. Hans Helmut Christmann, ed. (1977) Sprachwissenschaft des 19. Jahrhunderts, 85-105. (Wege der Forschung, 474.) Darmstadt: Wissenschaftliche Buchgesellschaft.)

Skinner, Stephen (1671) Etymologicon Linguce Anglicance, Seu, Explicatio vocum Anglicarum Etymologica ex propriis fontibus, scil. ex Linguis duodecim. London: Roycroft. 
Stevens, P. F. (1983) “Augustin Augier's “arbre botanique” (1801), a remarkable early botanical representation of the natural system". Taxon 32, 2: 203-211.

Stiernhielm, Georg (1671) "De linguarum origine Præfatio". In D. N. Jesu Christi SS. Evangelia ab Ulfila Gothorum in Moesia Episcopo circa annum à nato Christo CCCLX. Ex Grceco Gothicé translata, nunc cum parallelis versionibus, sveo-gothicâ, norraenâ, seu islandicâ, \& vulgatâ latinâ edita. Stockholmiae: Typis Nicolai Wankif.

\begin{abstract}
Kokkuvõte. Urmas Sutrop: Eesti jälg elupuu mõistes ja keelepuu teoorias. Käesolevas artiklis käsitletakse kõigepealt lühidalt nii hästi moodustatud kui ka hästi moodustamata puu-mudeleid. Seejärel kirjeldatakse August Schleicheri keelepuu mudelit ning võrreldakse seda Charles Darwini elupuu diagrammi ja metafooriga. Keelepuude ja elupuude arengut vaadeldakse ajalooliselt. Analüüsitakse nii varasemaid mudeleid - loodusastmikke - kui ka hästi moodustatud ja hästi moodustamata elupuu ja keelepuu mudeleid. Erilist tähelepanu pööratakse Eestiga seotud autoritele, kes on andnud oma panuse nii keelepuu kui ka elupuu mudeli väljatöötamisse ja arengusse: Georg Stiernhielm oli esimene, kes juba 1671. aastal joonistas ja avaldas keelepuu, Karl Eduard Eichwald avaldas loomade elupuu aastal 1829 ning Karl Ernst von Baer mõjutas nii otseselt kui ka kaudselt Charles Darwini elupuude mudeleid ja diagramme.
\end{abstract}

Märksõnad: puu-mudel, Karl Ernst von Baer, Charles Darwin, Karl Eduard Eichwald, August Schleicher, Georg Stiernhielm, Eesti 